\title{
APLIKASI MEDIA PEMBELAJARAN ALPHANUMERIK DAN PENGENALAN HEWAN UNTUK ANAK USIA PRA-SEKOLAH DENGAN MEMANFAATKAN TEKNOLOGI AUGMENTED REALITY
}

\author{
Darmawan Aditama \\ Universitas Muhammadiyah Gresik Gresik, awanaditama@umg.ac.id \\ Rizqi Putri Nourma Budiarti \\ Universitas Nahdlatul Ulama Surabaya Surabaya, rizqi.putri.nb@unusa.ac.id
}

\begin{abstract}
Abstrak
Perkembangan Teknologi Informasi dan Komunikasi (TIK) semakin meningkat dan telah merubah wajah baru pendidikan. Implementasi Teknologi Informasi dan Komunikasi (TIK) pada lembaga pendidikan yang saat ini perlu ditingkatkan dan sudah menjadi sebuah keharusan pada institusi pendidikan. Tidak menutup mata bahwa perguruan tinggi di Indonesia sudah sewajarnya tanggap terhadap perkembangan teknologi. Penggunaan Mobile Learning (M-Learning) sebagai penunjang proses belajar mengajar dirasa dapat menambah fleksibilitas dalam kegiatan belajar mengajar apalagi untuk anak usia prasekolah. Anak-anak pada usia ini harus diperkenalkan pada manfaat keberadaan teknologi. Agar dimasa depan, anak-anak pada usia ini tidak salah dalam memanfaatkan teknologi. Aplikasi M-Learning memberikan kemudahan bagi siswa didik dalam melakukan pembelajaran dimanapun dan kapanpun dengan menggunakan perangkat mobile. Kemampuan pembelajaran di fokuskan pada pembuatan aplikasi pembelajaran alphanumerik dan pengenalan hewan pada anak usia pra-sekolah. Karena dasar dari pendidikan adalah pembelajaran alphanumeric dan pengetahuan terkait hewan. Alphanumerik merupakan salah satu syarat utama bagi anak usia pra-sekolah untuk meningkatkan pemahaman dalam mata pelajaran yang diberikan di sekolah. Aplikasi $M$ Learning dibuat dengan memanfaatkan mobile android dan Augmented Reality.
\end{abstract}

Kata Kunci: M-Learning, Augmented Reality, Alphanumerik, Pengenalan Hewan.

\section{PENDAHULUAN}

Perkembangan Teknologi Informasi dan Komunikasi (TIK) yang semakin berkembang pesat dan memberikan wajah baru bagi pendidikan. Implementasi Teknologi Informasi dan Komunikasi (TIK) di lingkungan pendidikan sudah menjadi sebuah keharusan pada institusi pendidikan, tidak menutup mata bahwa perguruan tinggi sudah sewajarnya tanggap terhadap perkembangan teknologi. Penggunaan Mobile learning (M-
Learning) sebagai media pembelajaran dapat mendukung aktifitas proses belajar mengajar yang dirasa dapat meningkatkan fleksibilitas pada kegiatan belajar mengajar apalagi untuk anak usia prasekolah. Anak-anak pada usia ini harus diperkenalkan pada manfaat keberadaan teknologi. Agar dimasa depan tidak salah memanfaatkan teknologi.

Pembelajaran dengan menggunakan mobile learning merupakan salah satu pilihan yang bisa dilakukan dimanapun setiap saat, setiap waktu dan kapan- 
pun. Hal ini dikarenakan pembelajaran yang dengan media mobile learning didukung dengan harga perangkat yang dapat terjangkau oleh masyarakat dan sangat mudah diperoleh. Selain itu penggunaan dengan media mobile learning relatif lebih mudah bila dibandingkan dengan pembelajaran yang menggunakan perangkat komputer dimana hal ini juga mendorong semakin luasnya penggunaan mobile learning sebagai paradigma media pembelajaran yang bisa digunakan setiap saat.

Agar penyajian pembelajaran yang digunakan dapat menarik dan memberikan motivasi bagi siswa didik belajar secara mandiri, maka pengembangan proses belajar mengajar dapat dilakukan menggunakan teknologi informasi komunikasi dengan menempatkan materi pembelajaran pada media mobile atau smartphone. Penggunaan media sebagai solusi dalam pembelajaran siswa dapat menjadi salah satu alternatif jitu dalam menarik perhatian dan membuat siswa didik lebih terjaga dan lebih perhatian terhadap materi yang dipaparkan .

Aplikasi M-Learning memberikan kemudahan bagi siswa didik dalam melakukan pembelajaran dimanapun dan kapanpun melalui perangkat mobile. Kemampuan pembelajaran di fokuskan pada pembuatan aplikasi pembelajaran alphanumerik pada anak usia pra- sekolah. Karena dasar dari pendidikan adalah pembelajaran alphanumerik. Alphanumerik merupakan bekal utama bagi anak usia pra-sekolah dalam hal memahami setiap materi dalam mata pelajaran yang telah diberikan di sekolah.

Sudah tidak asing lagi diera dunia digital saat ini, bahwa solusi alternatif dalam mendukung kemampuan minat dan bakat anak generasi milenial saat ini dalam belajar berhitung aritmatika bisa dilakukan baik dengan penggunaan software atau aplikasi sebagai media pembelajaran baik berupa aplikasi dekstop, web-based ataupun mobilebased. Penggunaan aplikasi mobilebased salah satu nya adalah android. Android sering kali dijadikan pilihan dalam pembuatan media pembelajaran karena penggunaannya yang lebih mudah dan bisa dibawa kemanapun, hal ini menjadi alasan tambahan mengapa android dipilih sebagai media untuk membangun aplikasi ini. Mobile android telah menjadi candu yang tidak pernah lepas dari genggaman tangan sehingga mobile learning dipilih sebagai media belajar yang tidak dapat membuat jenuh peserta didik.

Penelitian ini bertujuan untuk membuat sebuah aplikasi yang menyajikan pembelajaran alphanumerik yang sengaja dikemas dalam bentuk permainan supaya dapat meningkatkan minat 
belajar anak usia pra-sekolah.

Dengan perkembangan teknologi saat ini, pemanfaatan teknologi yang baik akan sangat membantu untuk memberikan pembelajaran kepada anak-anak peserta didik. Apalagi teknologi yang dirancang dan dikonsep sedemikian rupa akan sangat menarik minat anak-anak untuk menggunakannya. Anak-anak di era modern sangat tertarik dengan game, dengan konsep yang baik maka kita seharusnya dapat memanfaatkan peluang dalam game tersebut. Dengan menyisipkan nilai atau manfaat pembelajaran didalamnya kita sudah bisa memberikan hiburan sekaligus pendidikan yang secara tidak langsung dapat membangun anak-anak kita.

Aplikasi pembelajaran ini dibagi menjadi tiga pengenalan, yaitu pengenalan karakter huruf, angka dan hewan. Dalam melakukan pencocokan bentuk karakter, siswa didik akan dikenalkan dengan teknologi terbaru yaitu Augmented Reality. Dengan memanfaatkan teknologi ini. Siswa didik akan dapat bermain dengan baik dan dapat merangsang system syaraf mereka. Karena siswa didik harus menemukan sendiri huruf atau angka yang dicari.

Augmented Reality adalah realitas tertambah, atau singkatan dalam bahasa inggris yang tidak asing lagi yaitu AR dimana mengambil istilah dari
Augmented Reality. Ronald T. Azuma, 1997 dalam artikelnya memaparkan bahwa AR sebagai percampuran bendabenda yang nyata maupun maya di dalam lingkungan real-nyata, dimana tampilan yang disajikan secara visual- interaktif dalam waktu nyata dimana di dalamnya terdapat integrasi benda-benda dalam bentuk tiga dimensi yang dipaparkan dengan benda maya yang terintegrasi dengan dunia nyata. Teknologi dalam penggabungan benda-benda nyata ke dalam bentuk maya ataupun sebaliknya didukung teknologi tampilan dan interaktivitas dari gambar-gambar yang dihasilkan melalui perangkat input dan sistem integrasi yang baik serta memerlukan penjejakan yang lebih efektif .

Dalam media AR ini, tidak hanya dilakukan penambahan benda-benda maya yang didalam lingkungan realnyata, melainkan realitasnya juga bertambah dan memiliki potensi dalam menghilangkan keberadaan benda-benda yang sebelumnya sudah ada. Di media AR ini, penambahan sebuah gambar pada lapisan maya sangat dimungkinkan untuk mengganti, maupun menyembunyikan keadaan sebenarnya pada lingkungan real-nyata sehingga tidak tampak pada pandangan pengguna media AR ini. Salah satu contohnya, ketika pada penggunaan AR ini didesain untuk 
menyembunyikan sebuah meja dalam lingkungan real-nyata, hanya dibutuhkan penggambaran lapisan representasi tembok dan penggunaan lantai kosong yang diletakkan pada posisi diatas gambar meja nyata berada, yang secara otomatis akan menutupi pandangan pengguna dari keberadaan sesungguhnya meja nyata.

\section{TINJAUAN PUSTAKA}

\section{Sistem Operasi Android}

Android merupakan perangkat lunak dalam bentuk sistem operasi yang mendukung untuk perangkat mobile berbasiskan linux yang didalamnya mencakup sistem operasi, middleware, dan beberapa aplikasi yang telah disediakan. Pertumbuhan android semakin pesat seiring semakin besarnya pengguna platform ini. Hal ini dikarenakan penggunaan platform android yang sangat mudah dan lengkap baik sistem operasinya, aplikasi dan perangkat pengembangan (mode developer pada android sangat mudah). Hal ini ditunjang dari segi market penggunaan aplikasi android dan berbagai dukungan yang sangat tinggi dari komunitas open source di dunia, sehingga platform android masih terus berkembang baik dari segi teknologi yang digunakan maupun dari segi penggunaan jumlah device yang digunakan di seluruh dunia.
Media pembelajaran bisa berupa apa saja, dan dengan perangkat mobile, sebuah konsep pembelajaran pengenalan Alphanumerik dan pengenalan hewan dibangun dengan tujuan memberikan hiburan dan pengetahuan kepada anakanak menggunakan sistem operasi Android. Android merupakan platform sistem operasi perangkat mobile milik Google, sistem tersebut secara bebas dapat dikembangkan oleh orang banyak, atau kita kenal dengan istilah Open Source.

Android terpasang pada perangkat mobile yang biasa kita sebut pula dengan smartphone dan tablet. Perangkat ini akan sangat sesuai dengan aplikasi media pembelajaran dimana target utama pengguna yang menggunakan aplikasi tersebut adalah anak-anak. Dengan layar sentuh akan sangat menarik untuk anakanak menemukan Alphanumerik, sehingga mereka dapat langsung menerapkan hasil belajar mereka pada perangkat itu juga.

\section{Augmented Reality}

Augmented Reality adalah realitas tertambah, atau singkatan dalam bahasa inggris dikenal AR dimana mengambil istilah dari Augmented Reality. Ronald T. Azuma, 1997 dalam artikelnya memaparkan bahwa AR sebagai percampuran benda-benda yang nyata 
maupun maya di dalam lingkungan realnyata, dimana tampilan yang disajikan secara visual-interaktif dalam waktu nyata dimana di dalamnya terdapat integrasi antar benda dalam bentuk tiga dimensi yang dipaparkan dengan benda maya yang terintegrasi dengan dunia nyata. Teknologi dalam penggabungan benda-benda nyata ke dalam bentuk maya ataupun sebaliknya didukung teknologi tampilan dan interaktivitas dari gambar-gambar yang dihasilkan melalui perangkat input dan integrasi yang baik serta memerlukan penjejakan yang lebih efektif.

Sebuah sistem yang dibangun pasti memiliki kelebihan dan kekurangan, tak terkecuali Augmented Reality. Kelebihan dari Augmented Reality adalah dapat dipaparkan sebagai berikut:

1) Tampilan lebih interaktif, 2) efektif dalam penggunaan visualisasi, 3) Dapat diimplementasikan secara luas dalam berbagai media, 4) Modeling obyek yang yang sederhana, karena hanya menampilkan beberapa obyek, 5) Pembuatan yang tidak memakan terlalu banyak biaya, 6) Pengoperasian sistem yang mudah.

Sedangkan kekurangan dari Augmented Reality adalah: 1) Sensitif terhadap perubahan sudut pandang, 2) Developer AR belum terlalu banyak, 3)
Memerlukan memori dalam jumlah besar pada peralatan yang dipasang.

Dengan menggunakan Augmented Reality $(A R)$ sebagai salah satu alternatif media pembelajaran siswa, diharapkan dalam proses belajar mengajar yang didapatkan menjadi lebih menarik bagi siswa. Manfaat lain yang diperoleh adalah media pembelajaran yang lebih maju dengan memanfaatkan perkembangan teknologi saat ini. Melalui Augmented Reality(AR) dapat menjadi salah satu solusi dalam penyediaan modul dan trainer yang biasanya cukup mahal serta untuk meminimalisir pembiayaan sekolah. Siswa tetap dapat melakukan praktikum dengan melihat barang seperti aslinya, namun disajikan bentuk penggambaran virtual .

Augmented reality menjadi teknologi yang sangat populer dimana tampilan yang diberikan menarik dan real-time. Sebuah permainan real-time dengan menggunakan marker untuk menampilkan animasi games secara 3D, Augmented Reality sendiri adalah sebuah teknologi yang menempatkan suatu gambar virtual dari grafis komputer pada dunia nyata, atau dengan kata lain penggabungan antara dunia nyata dengan dunia virtual, serta merupakan salah satu contoh aplikasi bidang seni dan teknologi yang cukup banyak di gemari saat ini. 


\section{Unity 3D Engine}

Unity 3D Engine adalah cross-platform pada game engine dimana perangkat lunaknya dikhususkan untuk penggunaan dalam membangun berbagai aplikasi maupun pembuatan media permainan. Unity dapat didefinisikan sebagai salah satu game development ecosystem dimana penggunaannya untuk membuat permainan atau aplikasi dalam berbagai macam platform baik console, desktop, dan mobile. Penggu-naan bahasa pemrograman utama dalam Unity adalah C\# dengan IDE Mono Develop. Selain itu, Unity juga menyediakan berbagai pilihan bahasa pemrograman lainnya dalam mengem-bangkan game, antara lain JavaScript, C Sharp (C\#), dan BooScript. Dalam penelitian ini penulis menggunakan bahasa pemrograman $\mathrm{C}$ Sharp (C\#) untuk mengembangkan aplikasi [6].

\section{Vuforia}

Vuforia merupakan Software Development Kit (SDK) untuk perangkat mobile dimana digunakan untuk pembuatan aplikasi menggunakan teknologi Augmented reality. Di dalam unity, Vuforia SDK sudah disediakan sebagai packege dalam unity. Vuforia SDK dapat mengkombinasikan kamera dalam perangkat mobile sebagai informasi masukan, sebagai mata elektronik yang mengenali penanda tertentu sehingga dapat muncul objek animasi di kehidupan nyata. Vuforia adalah SDK yang dikhususkan untuk penggunaan computer-vision based Augmented reality, yang memiliki interaksi tanpa batas karena dapat dikembangkan dalam teknologi dua dimensi maupun tiga dimensi.

\section{METODE PENELITIAN}

Penelitian difokuskan pada beberapa tahapan langkah-langkah penelitian dalam pembuatan aplikasi M-Learning (Mobile Learning) yang diaplikasikan pada TK Aisyiyah ranting palirangan.

Berikut tahapan-tahapan penelitian yang digunakan pada penelitian ini digambarkan pada Gambar 1.

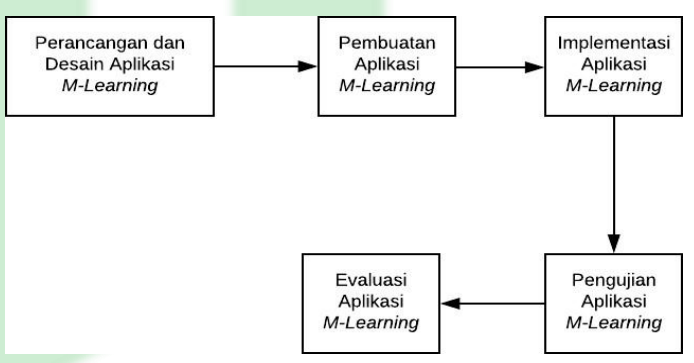

Gambar 1. Tahapan Penelitian Aplikasi $M$ Learning

\section{Perancangan Sistem}

Dalam bukunya jogiyanto, 1991 mengutarakan bahwa analisis dan desain sistem, serta perancangan sistem dapat dipaparkan sebagai berikut:

a. Tahapan setelah analisis dari siklus pengembangan system.

b. Tahap pendefinisian dari kebutuhan - 
kebutuhan fungsional.

c. Tahap persiapan untuk rancang bangun dan implementasi.

d. Tahapan penggambaran bagaimana suatu sistem dibentuk.

e. Tahapan selanjutnya berupa penggambaran perencanaan dan pembuatan sketsa ataupun pengaturan dari beberapa elemen yang terpisah ke dalam satu kesatuan yang utuh dan berfungsi.

f. Tahapan konfigurasi dimana hal ini termasuk dalam hal yang terkait dalam mengkonfigurasi dari komponen perangkat keras dari suatu sistem.

Perancangan sistem menyangkut proses berjalannya program (flowchart).

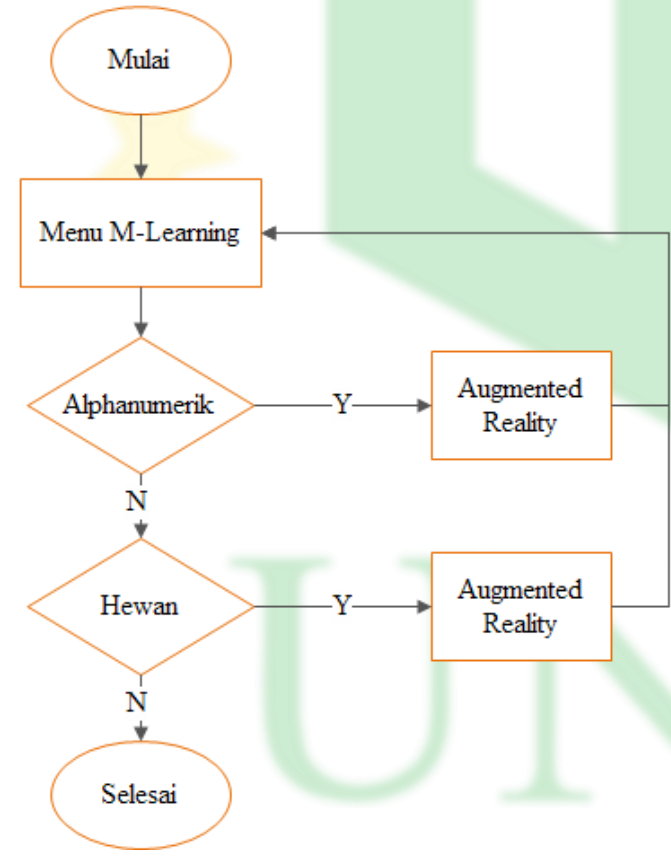

Gambar 2. Flowchart M-Learning

Ketika menjalankan Aplikasi yang dirancang user akan dipandu untuk memilih bermain tebak alphanumeric atau hewan menggunakan augmented reality. Setelah memilih permainan yang akan dimainkan. User akan berpindah dari halaman menu menjadi kamera.

Setelah kamera terbuka maka user tinggal mencari object yang cocok dengan soal. Object (alphanumeric / hewan) akan muncul (spawn) dengan random kordinat sehingga user harus mengarahkan kamera untuk mencari jawaban yang sesuai dengan soal.

User hanya memiliki 3 kali kesempatan untuk menjawab soal dengan salah. Jika ketiga kesempatan telah habis maka permainan berakhir. Didalam permainan juga telah disediakan object lain (waktu) yang berfungsi untuk memberikan tambahan waktu untuk user menjawab soal.

\section{Pembuatan Aplikasi}

Pada pembuatan aplikasi $M$ Learning yang dapat memperkenalkan alphabet dan hewan kepada anak usia pra-sekolah. Dilakukan dengan menggunakan kombinasi teknologi, diantaranya Sistem Operasi Android, software Unity 3D Engine, dan Vuforia. Penggabungan ketiga teknologi ini, digunakan dalam pembuatan aplikasi pembelajaran yang dibagi menjadi dua pengenalan, yaitu pengenalan alphanumerik dan hewan. Dalam melakukan pencocokan bentuk karakter, siswa didik akan dikenalkan dengan 
teknologi terbaru yaitu Augmented Reality. Dengan memanfaatkan teknologi ini. Siswa didik akan dapat bermain dengan baik dan dapat merangsang system syaraf mereka. Karena siswa didik harus menemukan sendiri huruf / angka dan jenis hewan yang dicari.

\section{Implementasi Sistem}

Sebagai implementasi sistem yang dilakukan setelah pembuatan aplikasi ini, dilakukan pengaplikasian software di TK Aisyiyah ranting palirangan. Dimana, pada penelitian ini sebanyak 30 siswa digunakan sebagai objek penelitian dan mencoba aplikasi yang telah dibuat.

\section{Pengujian Sistem}

Pada tahapan ini, pembuatan aplikasi M-Learning yang dapat memperkenalkan alphabet dan hewan kepada anak usia pra-sekolah dilakukan pengujian hasil aplikasi yaitu dengan melakukan kuisioner pada sebelum penggunaan aplikasi (pre-test) dan sesudah penggunaan aplikasi (post-test).

\section{Evaluasi Sistem}

Pada tahapan ini, dilakukan penilaian terhadap hasil pengujian sistem yang diperoleh dari kuisioner pre-test dan kuisioner post-test yang diberikan untuk mengetahui seberapa tingkat kebermanfaatan dan keberhasilan sistem yang diimplementasikan.

\section{HASIL DAN PEMBAHASAN}

\section{Hasil Implementasi}

Hasil yang dicapai pada penelitian ini adalah pembuatan aplikasi M-Learning untuk media pembelajaran yang dapat memperkenalkan alphabet dan hewan kepada anak usia pra-sekolah.

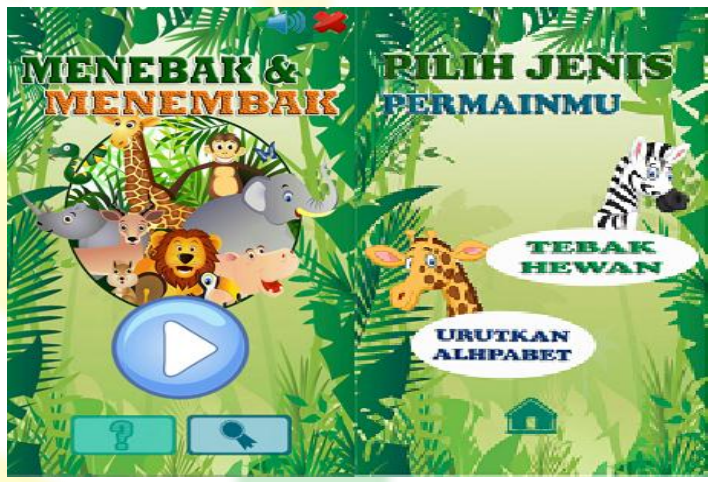

Gambar 3. Menu pada M-Learning

Gambar 2 menunjukkan pilihan menu pada aplikasi yang dibuat. Sengaja diberi ikon yang lucu untuk menumbuhkan minat anak didik untuk bermain dan belajar. Gambar 3 menunjukkan tampilan permainan pada aplikasi yang dibuat. Sengaja diberi ikon yang lucu untuk menumbuhkan minat anak didik untuk bermain dan belajar.

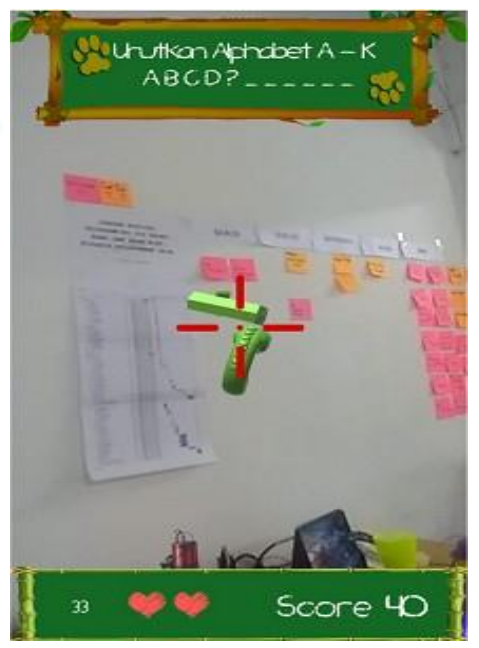

Gambar 4. Tampilan Permainan 
Gambar 4. menunjukkan tampilan aplikasi/permainan dengan cara mengarahkan target (crosshair) kearah hewan yang muncul. Player harus mengarahkan sesuai dengan soal yang diberikan. Setelah jawaban ditemukan tembak hewan dengan cara menekan layar handphone.

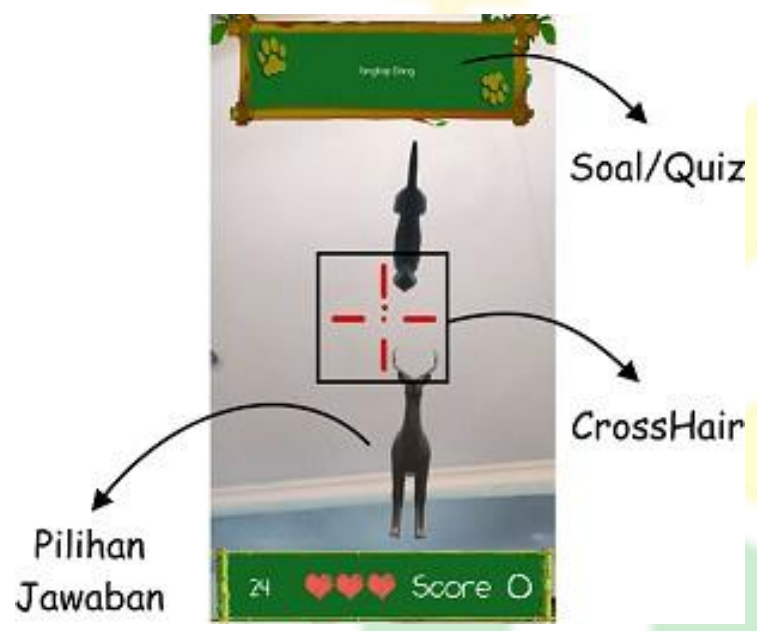

Gambar 5. Icon soal, target (crosshair) dan tampilan pilihan jawaban

Permainan berakhir jika nyawa yang dimiliki oleh player habis. Nyawa akan berkurang jika player salah menjawab soal. Sehingga player hanya memiliki 3 kesempatan gagal menjawab soal. Seperti terlihat pada gambar 5 .

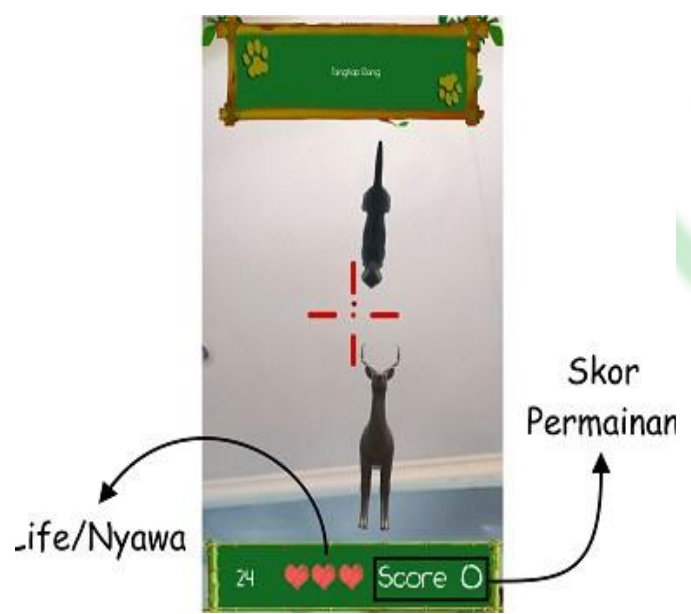

Gambar 6. Icon skor dan life
Pada gambar 6 dijelaskan waktu yang dimiliki oleh player untuk menemukan jawaban dari soal yang diberikan. Pada level 1 player memiliki waktu 60 detik untuk menemukan jawaban. Pada level 2 player memiliki waktu 75 detik untuk menemukan jawaban.

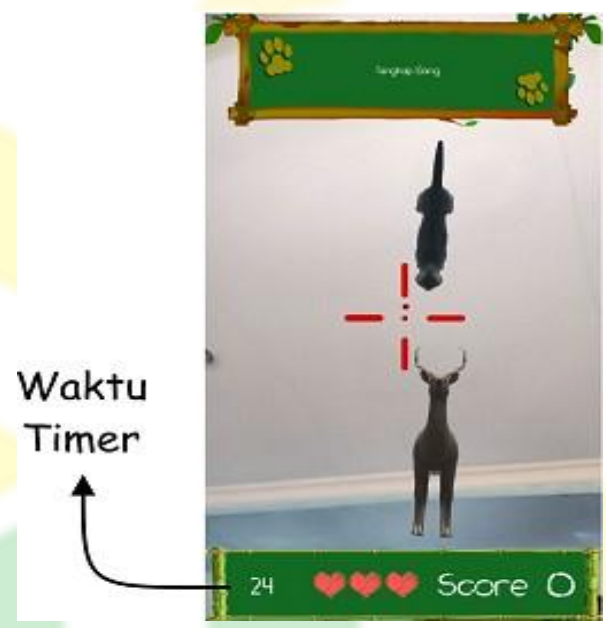

Gambar 7. Icon waktu

Gambar 7 memperlihatkan terdapat koin yang akan melayang-layang bersamaan dengan hewan-hewan yang menjadi jawaban dari soal. Fungsi koin adalah untuk menambahkan skor permainan selain dengan menjwab soal.

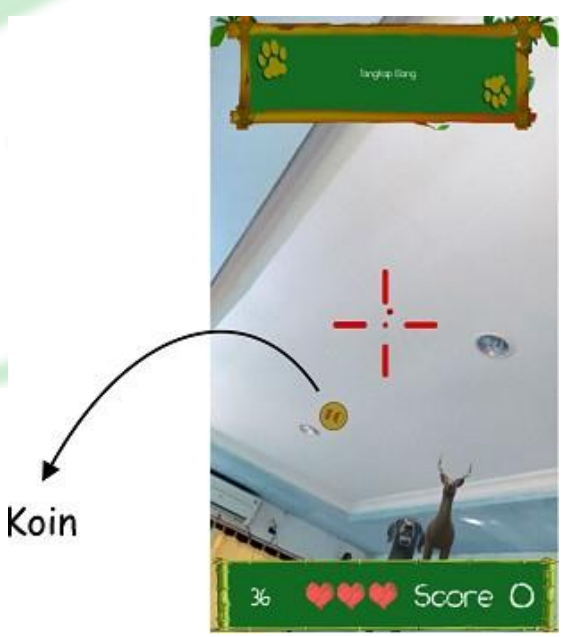

Gambar 8. Ikon koin 
Gambar 8 memperlihatkan terdapat halangan berupa bom yang akan melayang-layang bersamaan dengan hewan-hewan yang menjadi jawaban dari soal. Jangan salah menembak ikon bom karena akan membuat permainan berakhir.

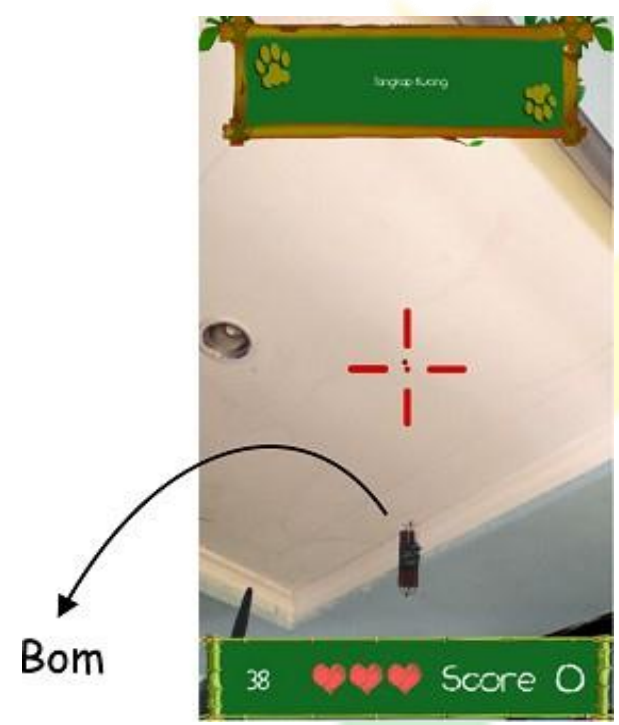

Gambar 9. Ikon Bom

Gambar 9 memperlihatkan terdapat ikon jam yang melayang-layang bersamaan dengan hewan-hewan yang menjadi jawaban dari soal. Fungsi ikon jam adalah menambah waktu bagi player untuk menemukan jawaban soal.

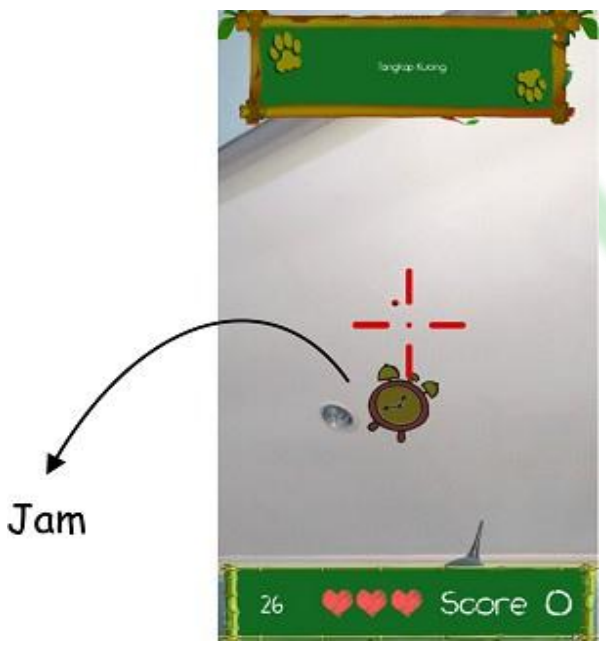

Gambar 10. Ikon Jam
Permainan berakhir jika player tidak dapat menjawab soal sebanyak tiga kali. Ataupun kehabisan waktu dan salah menekan pilihan bom. Jika permainan berakhir akan muncul tampilan yang menunjukkan tampilan akhir seperti pada Gambar 10.

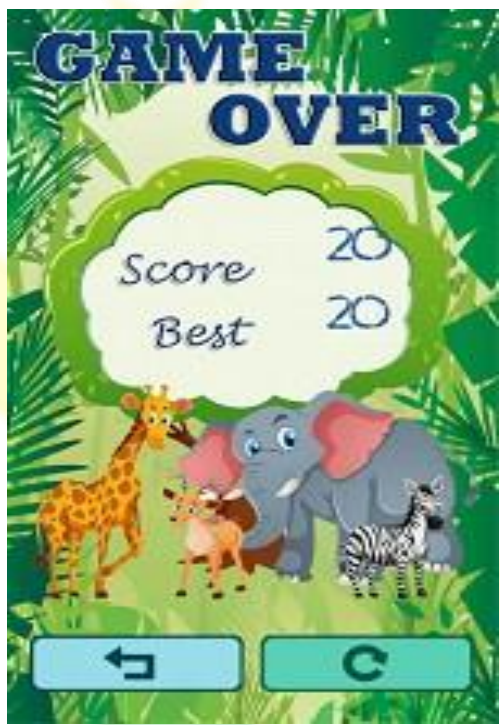

Gambar 11. Tampilan Akhir Permainan

a. Hasil Pengujian dan Evaluasi Sistem

Sebagai hasil pengujian dan evaluasi sistem dilakukan melalui pemberian kuisioner penggunaan aplikasi yang sudah dibuat yaitu aplikasi M-Learning yang dapat memperkenalkan alphabet dan hewan kepada anak usia pra-sekolah. Pada tahap pengujian dari aplikasi yang telah dibuat maka dilakukan pembagian kuisioner pada tiga puluh siswa dengan pemberian kuisioner sebelum penggunaan aplikasi (pre-test) dan sesudah penggunaan aplikasi (post-test). Dari beberapa pertanyaan yang diajukan pada saat pre- 
test dan post-test dilakukan diperoleh hasil sebagai berikut:

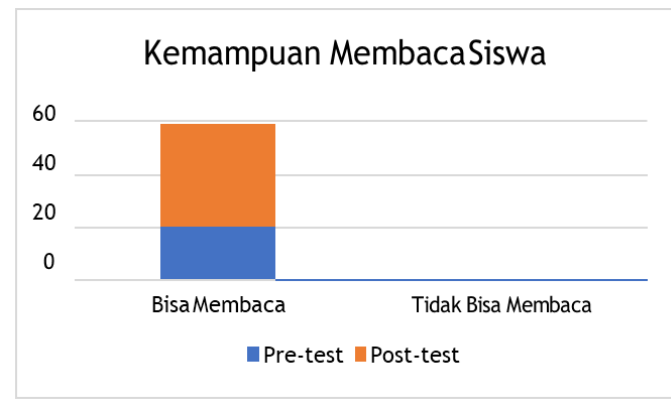

Gambar 12. Kemampuan membaca SiswaSaat Pre-testdan Post-Test

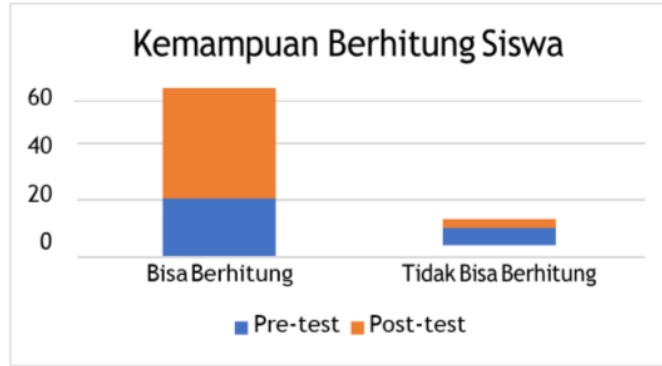

Gambar 13. Kemampuan Berhitung SiswaSaat Pre-Test danPost-Test

Berdasarkan Gambar 11 dan Gambar 12, dapat dimati bahwa sebelum dan sesudah penggunaan aplikasi Mlearning sebagai media pembelajaran siswa untuk anak usia pra-sekolah terdapat peningkatan persentase siswa dapat membaca sebesar $7 \%$ dari hasil pre-test sebesar $83 \%$ dan hasil post-test 90\%. Begitu pula dengan peningkatan persentase siswa dapat berhitung sebesar $10 \%$ dari dari hasil pre-test sebesar $77 \%$ dan hasil post-test $87 \%$. Setelah penggunaan aplikasi M-Learning aplikasi alphanumerik dan pengenalan hewan, terjadi peningkatan terhadap minat baca siswa dengan menggunakan aplikasi ini sebesar 87\%. Hal ini berdasarkan hasil kuisioner yang ditanyakan kepada siswa, dimana proses belajar dan pembelajaran membaca dan berhitung dengan menggunakan aplikasi M-Learning dapat meningkatkan minat mereka untuk membaca yang terlihat pada Gambar 13.

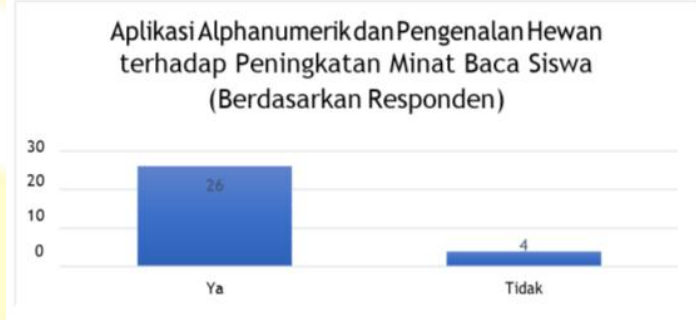

Gambar 14. Aplikasi Alphanumerik dan Pengenalan Hewan terhadap Peningkatan Minat Baca

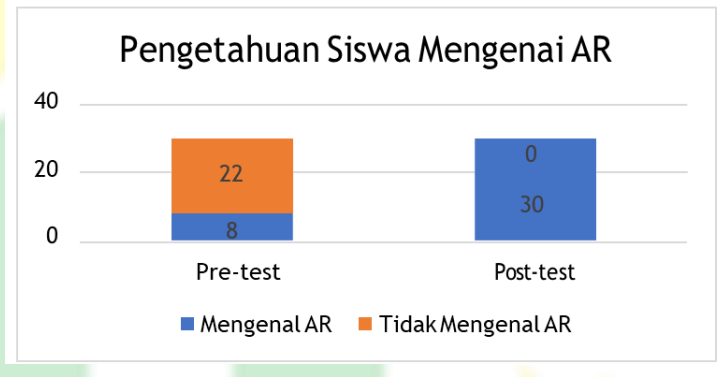

Gambar 15. Pengetahuan Siswa Mengenai AR

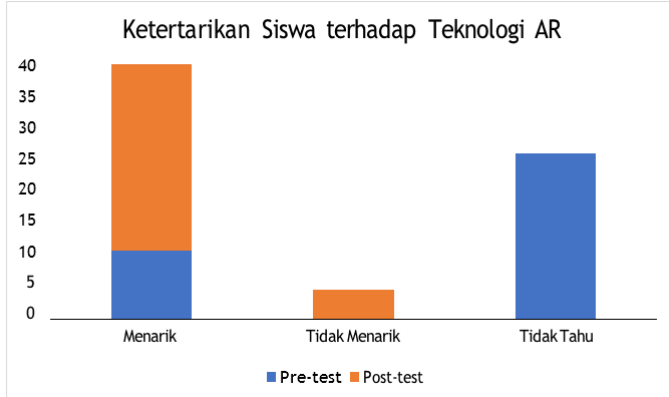

Gambar 16. Ketertarikan Siswa Terhadap Teknologi AR

Berdasarkan Gambar 13 dan Gambar 14, dapat dimati bahwa sebelum dan sesudah penggunaan aplikasi $M$ learning sebagai media pembelajaran siswa untuk anak usia pra-sekolah 
dilakukan yang sebagian besar siswa prasekolah belum tau mengenai teknologi AR (Augmented Reality). Hasil yang diperoleh menunjukan peningkatan prosentasi pengenalan teknologi $\mathrm{AR}$ di siswa pra-sekolah dan peningkatan ini juga meningkatkan ketertarikan siswa terhadap teknologi AR (Augmented Reality).

Hasil peningkatan persentase pengenalan teknologi AR ini dapat berhitung sebesar $73 \%$ dari dari hasil pretest sebesar $23 \%$ saja yang mengenal teknologi AR ini dan hasil post-test $100 \%$ yang mengindikasikan siswa sudah mengenal teknologi AR. Setelah penggunaan aplikasi M-Learning aplikasi alphanumerik dan pengenalan hewan, terjadi peningkatan atas ketertarikan siswa terhadap teknologi AR ini diperoleh persentase hampir 90\% yang mayoritas siswa usia pra-sekolah tertarik aplikasi alphanumerik dan pengenalan hewan menggunakan teknologi AR ini.

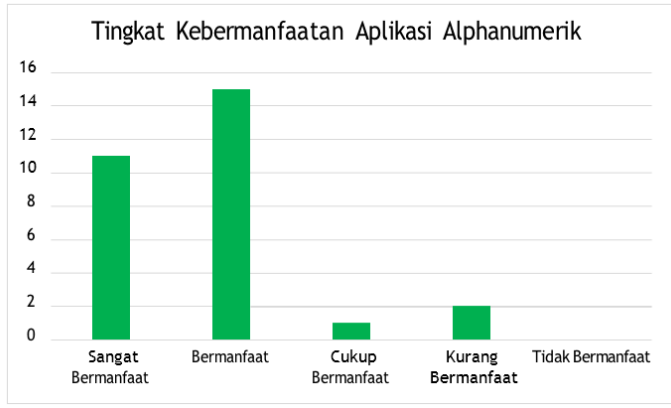

Gambar 17. Tingkat Kebermanfaatan Aplikasi Alphanumerik

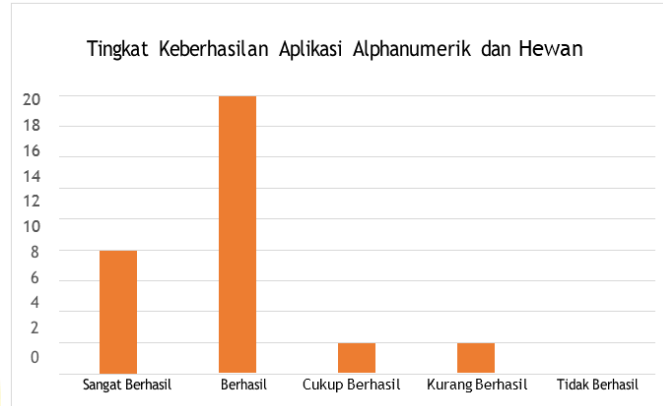

Gambar 18. Tingkat Keberhasilan Aplikasi M-learning

Dari hasil kuisioner yang diberikan, dari Gambar 15 diperoleh persentase dari tingkat kebermanfaatan aplikasi M-learning alphanumerik dan pengenalan hewan menyatakan $37 \%$ sangat bermanfaat, $50 \%$ bermanfaat, $3 \%$ cukup bermanfaat, dan $7 \%$ kurang bermanfaat.

Sedangkan untuk hasil pengujian aplikasi yang diberikan melalui kuisioner diperoleh persentase tingkat keberhasilan aplikasi M-learning alphanumerik dan pengenalan hewan sebesar $27 \%$ sangat berhasil, $60 \%$ berhasil, $7 \%$ cukup berhasil, dan 7\% kurang berhasil. Dari hasil diatas dapat dipaparkan bahwa aplikasi M-learning alphanumerik dan pengenalan hewan sangat bermanfaat dalam meningkatkan minat baca siswa dan aplikasinya berhasil dalam mengenalkan teknologi AR kepada siswa usia prasekolah.

\section{KESIMPULAN}

Berdasarkan hasil dan pembahasan yang telah dipaparkan, dapat disimpulkan 
bahwa Aplikasi M-Learning untuk media pembelajaran menggunakan teknologi AR bermanfaat dalam meningkatkan minat baca dan belajar siswa usia prasekolah dan berhasil dalam mengenalkan teknologi AR melalui media pembelajaran dimana dalam proses pengenalan AR ini menggunakan handphone android sebagai salah satu pilihan media ajar bagi siswa didik. Hal ini ditinjau dari hasil yang diperoleh dalam peningkatan persentase pengenalan teknologi AR ini sebesar 73\%. Aplikasi yang telah dibuat, kedepannya masih akan dilakukan pengembangan lebih lanjut dengan penambahan fitur-fitur yang lebih menarik. Pengembangan lainnya dengan penggunaan teknologi ARCORE yaitu platform augmented reality dari google yang bisa digunakan untuk media pembelajaran selanjutnya. Karena sudah sewajarnya media pembelajaran memanfaatkan kecanggihan teknologi. Apalagi penggunaan handphone android yang tidak asing lagi bagi semua kalangan masyarakat.

\section{REFERENSI}

Abdul, Majid. 2012. Perencanaan Pembelajaran. Bandung: Rosda Karya

Azhar Arsyad. 2003. Media Pembelajaran. Jakarta: PT Raja Grafindo Persada.

Azuma, Ronald T. (August 1997). "A Survey of Augmented Reality".
Presence: Teleoperators andVirtual Environments.

Ilmawan Mustaqim, 2017. Pengembangan Media Pembelajaran Berbasis Augmented Reality: Jurnal Edukasi Elektro

Jogiyanto, H.M., 1991, Analisis dan desain sistem informasi, Irvan, Jakarta

Mas Ali Bahtiar ,2011, “ Sistem Augmented Reality Untuk Animasi Games Menggunakan Camera Pada Pc"

P. Inc, "Vuforia Developer Portal," Vuforia, 2016. [Online]. Available: https://developer.vuforia.com/. [Accessed 22 2016].

Unity, "Game engine, tools and multi platfrom," nity, [Online]. Available:http://unity3d.com/unit. [Accessed 9 april 2014]. [2] 